\title{
Lessons learned from humoral responses of HIV patients
}

\section{Laura E McCoy ${ }^{1^{*}} \&$ Áine McKnight ${ }^{2^{*}}$}

1. Division of Infection \& Immunity, University College London

Cruciform Building, London WC1E 6BT. Tel: +44 (0) 2031082137.

L.mccoy@ucl.ac.uk

2. Blizard Institute, Barts and The London School of Medicine and Dentistry, 4

Newark Street, London, E1 2AT. Tel: +44 (0) 2078822483.

a.mcknight@qmul.ac.uk

${ }^{*}$ correspondence

\section{Abstract}

Purpose of review: Since 2009 many broadly neutralizing antibodies against HIV have been identified yet there is still no vaccine capable of inducing such antibodies in humans. This review considers the early observations of HIV sera neutralization in light of more recent studies and highlights areas for future research.

Recent findings: Large clinical cohort studies using standardized neutralization assays and pseudoviruses derived from primary isolates have shown that $10-30 \%$ of HIV infections result in some level of serum neutralization breadth. However, less than $10 \%$ of individuals develop a greater breadth of neutralization and are termed elite neutralizers.

Summary: During HIV infection many individuals develop strain-specific neutralization against their viral quasispecies, and similar immunogen-matched activity can now be induced in animal models. However, only in a minority of infections do broadly neutralizing antibodies develop. Therefore, understanding how the viral diversity, host immune environment and antibody repertoires intersect to support the generation of neutralization breadth in elite neutralizers could provide guidelines as to how to improve immunization responses.

Keywords: HIV, neutralization, antibody, serum, infection 


\section{Introduction:}

The unusual degree of genetic variability of HIV-1, especially in the env gene that encodes the target for neutralizing antibodies, became apparent early on in the epidemic (1-5) and brought with it the concern that it would be difficult to develop an efficacious vaccine that could induce broadly neutralizing antibodies (bnAbs). Early studies that examined the neutralization of HIV-1 by human sera from infected individuals set the agenda for the next 30 years of HIV vaccine research (6-14). These studies, allayed some fear; as although much neutralizing activity was strainspecific at least some individuals developed neutralizing antibodies that were effective across diverse HIV-1 strains from around the globe $(15,16)$. Thus, despite the diversity in the HIV envelope protein (Env) there were conserved neutralizing epitopes. This review will provide an overview of the subsequent 30 years of research that resulted in a detailed picture of the development of neutralizing humoral responses during HIV infection.

\section{Early studies of HIV neutralization}

An obvious target for neutralizing antibodies was the viral interaction with the cell surface receptor CD4, which had already been identified as the major receptor for HIV entry into cells (17). Indeed the 'group specific' response was shown to include antibodies that inhibited CD4-envelope binding $(18,19)$. The entry of HIV into its target cell is mediated by the highly glycosylated gp120 Env subunit, which is secured on the virion surface by the transmembrane gp41 Env subunit (20). Comparison of the gp120 sequences from various HIV isolates distinguished five variable regions (V1-V5) (4). The first four variable regions are exposed and held in loops by disulphide bonds (20). While the conserved regions of gp120 form a discontinuous structure, identified by mutagenesis to interact with CD4 (21-23). Thus, the CD4 binding site (CD4bs) was a likely candidate for conserved neutralizing epitopes. It was not understood at this time, but later became known, that when viral 
gp120 binds to CD4 it induces conformational changes that expose the V3 loop (24), which is the principal determinant of chemokine co-receptor interaction (CCR5 and CXCR4) (25-27). This CD4-induced exposure is indicated by the enhanced binding of several gp120-specific antibodies, in addition to those that recognize the V3 loop and CD4 binding site (28-31). These CD4-induced (CD4i) antibodies (32), similar to V3-loop antibodies, efficiently block the binding of gp120-CD4 complexes to the chemokine receptor (33-35).

Despite the early optimism that broadly neutralizing targets could be identified a stumbling block quickly became apparent. Namely, that bnAb responses would be difficult to recapitulate in a vaccine using recombinant Env $(6,36)$. This was suggested because the first neutralizing antibodies to arise in human infection or in experimental infection of chimpanzees, targeted the V3 loop and only neutralized in a type-specific manner (37-39). Furthermore, group-specific antibodies (now termed broadly neutralizing) developed only slowly, between one and two years after infection and not in all patients (15). These early studies were usually too small to make accurate estimates of how long it takes to develop bnAbs or in what fraction of infected patients they arose (40-42). Subsequent studies used viral isolates or Env clones derived directly from patients (autologous viruses) (43-45). The same picture emerged; variability among patients with respect to the time needed to develop autologous neutralization and a robust broadening of the response with time in only a minority of individuals. However, these early studies were plagued by cohort variability and a lack of consistency between neutralization assays employed including the use of viruses with varying degrees of neutralization sensitivity (46). Thus, the molecular details underpinning these responses would be required to generate a clear picture of the development of HIV neutralizing antibodies in vivo.

\section{How do bnAbs develop during infection?}


A key and consistent observation in studies of natural infection so far is that the 10$30 \%$ of individuals whose serum is broadly neutralizing (Table 1 ), first make a strainspecific response and then eventually shift to make a broader neutralizing response. Understanding how this shift to broad neutralization is achieved is key to vaccine development. How can it be mimicked to generate bnAb responses, both as an adjunct to therapy and in a classical protective vaccine? Detailed studies of bnAbs from mainly from the $1-10 \%$ of individuals with elite serum neutralization (as defined in each cohort - see Table 1) have begun to paint a picture that suggests that there are a number of ways to achieve bnAb activity. To date, five major bnAb sites have been identified: the CD4bs, the high mannose patch, the Env trimer apex, the gp120gp41 interface and the membrane proximal region (MPER), and these are extensively reviewed elsewhere $(57,58)$. It will be important know if this broad antiviral activity is achieved by multiple antibody lineages or by one or a few dominant expanded families. Studies on serum with bnAb-specific mutant viruses suggest that, at least in some cases, a limited number of epitopes are targeted within individuals $(55,59,60)$. There are notable examples of expanded bnAb families within particular individuals that reconstiute their serum neutralization response (61-64). For example, one 15-year longitudinal study of the CD4bs-specific VRC01 bnAb family shows how the virus and antibody response mutate in a "cat and mouse" fashion during infection (65). In addition, structurally and genetically similar bnAbs to VRC01 have been identified in other HIV-infected people $(66,67)$ although it is important to note that neutralizing epitopes can be targeted by genetically unrelated bnAbs (68-70).

How different HIV-specific antibody families impact one another during infection is relatively unknown. However, there is one intriguing example where a separate antibody family appears to help the development and expansion of a bnAb lineage within a particular individual (71). Strikingly, the cooperating antibody lineage was later found to develop neutralization breadth independently (72). This provides 
support for the idea that the development of breadth is a stepwise process that will require sequential immunogens to guide the antibody response along the desired maturation pathway. This concept is also supported by a number of observations: Firstly, that early less-mutated bnAb family members have a limited degree of neutralization breadth (73); and secondly, some good news, that specifically designed immunogens (74) can re-elicit this level of breadth in Knockin mice which encode the bnAb precursor (75). Notably, the sequential immunogens used to elicit these bnAb-like antibodies were closely related allowing boosting of the preceding antibody response. However, in genetically outbred animal models, immunization largely only produces autologous neutralization of primary isolates. Recently, this has been found to be due in part to immunogenic autologous neutralizing epitopes accessible due to holes in the glycan shield of Env (76). This is reminiscent of the specificity of autologous neutralization often observed in natural infection (45). Therefore, the field has now produced antibodies by immunization that resemble the early neutralizing specificities induced during infection. Thus, the next step is to understand how neutralization breadth develops and mimic that by vaccination.

Fundamental to this next step is to clearly define the involvement of strainspecific antibodies in the development of breadth. One study has suggested breadth can arise to the same site as the early autologous neutralizing response, but with the broad antibody actually binding the $\mathrm{N}$-linked glycan that enabled the virus to escape from the autologous neutralization (77). It seems unlikely this was due to direct affinity maturation of the autologous antibodies to recognise the $\mathrm{N}$-linked glycan. More feasible is that viral escape resulted in heightened variation in this region (including the additional glycan site) that triggered the generation of de novo bnAb lineages. However, apart from this example (77), it has been observed that, some early bnAb family members can only neutralize in the absence of specific glycan sites proximal to their epitopes. Such glycan shields are then tolerated by the related 
fully matured bnAbs $(78,79)$. In summary, the large body of work on bnAb lineages to date has provided clues as to how breadth develops, and the significance of the glycan shield in restricting neutralization breadth. Therefore, understanding what role, if any, strain-specific responses play in the step-wise development of neutralization breadth could suggest potential shortcuts to inducing breadth by immunization.

\section{Features associated with the development of bnAbs}

To recapitulate the shift from autologous to broad neutralization in vaccination it will also be valuable to understand why this occurs in some cases of natural infection and not others. To date, there are features associated with the development of neutralization breadth but no absolute predictive markers. The most consistent predictive trait of broad neutralization is a greater time of untreated infection, hence the preponderance of long-term non-progressors (LTNP) in broadly neutralizing cohorts $(55,56,80,81)$. Greater length of untreated infection occurs concurrently with greater viral diversity as quasi-species develop from the estimated 1-3 founder viruses (82). Furthermore, it has been suggested that greater diversity during the earliest stages of infection may have more influence on the development of breadth (83). However, in contrast to its association to the development of breadth, HIV Env sequence diversity poses a great barrier to the elicitation of bnAbs due to the extensive level of variation as reviewed in (84) and (85). In addition, Env adopts diverse conformational states, including non-infectious forms that can act as decoys for the immune response and by combining these multiple levels of variation HIV routinely escapes from host antibodies in 'a mutational arms race' $(86,87)$. Nevertheless, studies have suggested that viral subtype diversity can be overcome (88) and particular Env signatures are associated with the development of breadth (89). Moreover, intra-host Env diversity and viral escape from early neutralizing responses have been suggested to drive the maturation of broader responses (61, 
90). Thus, while Env diversity is a major roadblock to developing a protective antibody response following immunization paradoxically it is also a probable trigger of bnAb development.

Another key aspect of the development of broad HIV neutralization is the host immune system. The role of particular bnAb genetic precursor prevalence may play a role but has not been directly assessed in large cohort studies and is expertly reviewed elsewhere (91). There have been limited reports on the role of immune cell subsets, primarily that low CD4 counts correlate with breadth $(49,52,55)$, but this could potentially be related to high viral load. In addition, neutralization breadth has been associated with higher levels of T follicular helper (TFH) cells expressing PD1 in human subjects (92). TFH cells have also been found to be important in the development of broad antibody responses in non-human primate infections (93). Recent data from a very large human cohort show a trend to greater likelihood of bnAb-like serum responses in individuals of African ethnicity (56). Furthermore, a separate genome-wide association study in the Amsterdam Cohort found singlenucleotide polymorphism in MHC and HLA-B to be most strongly associated with breadth but not significant at a genome level (94). These observations suggest the overall host immune enivronment plays a role in the generation of bnAbs, as do studies showing that more rapid development of neutralization breadth can occur $(<1$ year). Particularly as this can occur in immunlogically distinct situations, such as transmission following injecting drug use (95) or from mother-to-child (96). Therefore, there is a need to further elucidate the role of host biology in the development of bnAb responses.

\section{The bnAb revolution}

Over the last decade the identification of bnAbs has revolutionized our understanding of the humoral response to $\operatorname{HIV}(57,97)$. The rapid isolation of so many bnAbs was 
possible due to advances in screening assays to identify individuals with broadly neutralizing serum as reviewed in (58). Critically, this involved the generation of large panels of Env pseudoviruses derived from primary isolates and categorization of their neutralization sensitivity, to exclude easily neutralized strains (98-100). These tools enabled neutralization breadth to be investigated in large cohort studies as summarized in Table 1 (47, 48, 50, 52-55). A clearer picture emerged; breadth of neutralization develops in $10-30 \%$ of individuals generally $2-3$ years after infection, despite the use of different definitions of breadth, virus panels and clinical populations between studies. Notably, elite neutralization, where breadth is equivalent to that seen with individual bnAbs, is less frequent, arising in $1-10 \%$ of individuals (Table 1). These large cohort studies are largely consistent with early observations of the rapid rise of autologous neutralization activity followed by the later, and less frequent, development of breadth $(43,44)$. Additionally, longitudinal serum studies have also shown the early development of autologous neutralization and resulting selection of viral escape mutations within individuals $(45,101,102)$. These strain-specific responses have been seen as early as two weeks post seroconversion and escape seen in response to low titers of autologous neutralizing antibodies (103). However, despite the fact that viral Env mutation within the host is largely driven by the need to escape the autologous neutralizing response, there is no apparent consequent loss of viral fitness (104) which raises the question of how effective humoral responses are after transmission during chronic infection?

Early studies that attempted to correlate neutralizing antibodies with protection were disappointing. There was no decline in viremia with the development of either autologous or broad neutralization $(43,44,105,106)$. Indeed, one study suggested that patients could harbor viruses sensitive to neutralization despite the presence of serum antibodies that potently neutralize these particular strains (107). Nor is there evidence that development of neutralization breadth improves patient 
prognosis $(51,108)$. The observation that broad neutralization is predominantly found in LTNP compared to rapid progressors $(47,49,51,53)$ may be attributable to sustained exposure to the viral Env antigen over long periods. In contrast rapid progressors become virally suppressed on treatment, which limits antigenic stimulation Despite these shortcomings the evolution of neutralization escape mutants in vivo was often clearly observed $(44,45,109)$. Furthermore, contemporary circulating HIV strains are more resistant to bnAbs compared to historical strains $(110,111)$. This suggests that overall there is evolutionary pressure on HIV to escape the onslaught of neutralization activity within individuals that controls diversification of the virus to some degree. In agreement with this, it is known that bnAbs can protect from infection in animal models, reviewed in (112), and recently human bnAb therapy has increased time to viral re-bound (113). Furthermore, preexisting anti-HIV antibodies have been reported to prevent the emergence of escape mutants to the administered bnAb (114) further supporting the idea of using bnAbs to treat chronic infection.

\section{Conclusion}

Many lessons have been learnt from studying the humoral response to HIV both in terms of serological studies and characterization of bnAbs and their family members. First, antibodies can be effective against HIV from the observation that the presence of early neutralizing antibodies drives the evolution of the viral Env within the host. Second, HIV bnAbs possess a level of neutralization breadth and potency previously thought impossible, renewing hope that a protective vaccine can be developed. Third, although virus can overcome neutralizing antibodies if it is established in the host before antibodies develop, as in natural infection, but not if antibodies are present in advance, as in passive transfer studies. Fourth, development of breadth is a question of balance; not only is diversity important but 
so too is time. High enough viral diversity over at least a year of infection is generally needed to stimulate a bnAb response but excessive viral replication, resulting in rapid progression and immune dysregulation, will not favour breadth. Finally, absolute predictors of neutralization breadth have not been identified. This suggests additional factors should be investigated such as the balance of different antibody specificities and lymphocyte subsets, along with genetic host factors. However, the interplay of host and viral factors that result in broad neutralization will likely vary between individuals, as HIV bnAbs are a diverse group which can arise from multiple pathways of antigenic stimulation. In summary, despite great advances in our understanding of humoral responses to HIV, what controls the tipping point that leads to broad neutralization remains to be defined.

\section{Key points:}

- Despite early optimism neutralizing responses are difficult to recapitulate in a vaccine

- Clinical cohort studies show that broad neutralization occurs in $10-30 \%$ of HIV infections

- Elite HIV serum neutralization is seen in $<10 \%$ of individuals

- More research is needed to understand the shift from strain-specific to broad HIV neutralization during infection and how it varies between different people.

\section{Acknowledgements:}

The authors would like to thank Professor Paul Clapham for critical reading of the manuscript.

\section{Financial support and sponsorship:}

L.E.M receives support from an FP7 Marie Curie International Outgoing Fellowship for Career Development number 623038.

Conflicts of interest: None. 
Figure legends:

Table 1: Selected serological studies assessing breadth of neutralization response in HIV infection.

Summary data from the indicated cohort studies which have attempted to measure breadth and potency of HIV neutralization in serum samples. Abbreviations: IAVI = International AIDS Vaccine Iniative, NIH = National Institutes of Health. 


\begin{tabular}{|c|c|c|c|c|}
\hline Cohort & $\begin{array}{l}\text { Viruses } \\
\text { screened }\end{array}$ & $\begin{array}{c}\text { No. } \\
\text { patients }\end{array}$ & Author defined breadth & Time frame \\
\hline \multirow{4}{*}{ IAVI Protocol G (47) } & Multiple panels: & $N=1798$ & & \multirow{4}{*}{ Single time point: 3 years onwards } \\
\hline & 101 virus panel & $\mathrm{n}=101$ & Broad $=45 \%$ had an IC50 titer of $\geq 150$ for viruses from $1-3$ clades & \\
\hline & $\begin{array}{l}15 \text { of above } \\
\text { viruses }\end{array}$ & $n=463$ & $\begin{array}{c}\text { Broad }=36 \% \text { had IC50 titers of } \geq 150 \text { for viruses from }>4 \text { clades } \\
\text { Intermediate }=51 \% \text { had an IC50 titer of } \geq 100 \text { for viruse from } 1-3 \text { clades }\end{array}$ & \\
\hline & $\begin{array}{l}6 \text { representative } \\
\text { viruses }\end{array}$ & $n=1234$ & $\begin{array}{c}\text { Broad }=34 \% \text { had IC50 titer of } \geq 100 \text { against }>4 \text { clades, Elite breadth }=1 \% \text { had mean IC50 } \\
\text { titer of } 1: 500 \text { to majority viruse from }>4 \text { clades. }\end{array}$ & \\
\hline $\mathrm{NIH}(48)$ & 5 virus panel & $n=113$ & $\begin{array}{c}\text { Broad }=33 \% \text { neutralized } 4 / 5 \text { viruses, Intermediate }=33 \% 3 / 5 \text { viruses, } \\
\text { no breadth }=29 \% 0 \text { or } 1 / 5 \text { viruses }\end{array}$ & Single time point: 1 year onwards \\
\hline Amsterdam Cohort (49) & 28 virus panel & $\mathrm{n}=35$ & $\begin{array}{c}\text { Broad }=I C 50>100 \text { for }>50 \% \text { of viruses per subtype, from }>3 \text { subtypes, } 20 \% \text { broad at } 2 \\
\text { years, } 31 \% \text { broad at } 4 \text { years }\end{array}$ & $\begin{array}{l}\text { Longitudinal: breadth observed } 2 \\
\text { and } 4 \text { years after seroconversion }\end{array}$ \\
\hline $\begin{array}{l}\text { South African National Blood } \\
\text { Services (50) }\end{array}$ & 10 virus panel & $n=70$ & Broad $=23 \%$ neutralized all 10 viruses & Single time point: 180 days onwards \\
\hline $\begin{array}{l}\text { Amsterdam Cohort } \\
\text { (51) }\end{array}$ & 23 virus panel & $\mathrm{n}=82$ & Broad $=33 \%$, moderate $=48 \%$ and no breasth $=20 \%$ & $\begin{array}{l}\text { Single time point: } \sim 35 \text { months after } \\
\text { seroconversion }\end{array}$ \\
\hline $\begin{array}{l}\text { Caprisa Cohort } \\
\text { (52) }\end{array}$ & 44 virus panel & $n=40$ & Broad $=17.5 \%$ neutralized $>40 \%$ of viruses & $\begin{array}{l}\text { Longitudinal: peak titer at } 3 \text { years } \\
\text { after seroconversion }\end{array}$ \\
\hline $\begin{array}{l}\text { Ragon Institute } \\
\text { (53) }\end{array}$ & 20 virus panel & $\mathrm{n}=17$ & Broad $=29 \%$ neutralized $75 \%$ viruses & $\begin{array}{l}\text { Longitudinal: breadth observed at } 1- \\
\qquad 2.5 \text { years }\end{array}$ \\
\hline Multiple (54) & 219 virus panel & $\mathrm{n}=205$ & Broad $=50 \%$ neutralized $>50 \%$ of viruses, Elite breadth $=10 \%$ neutralized $90 \%$ of viruses & $\begin{array}{l}\text { Single time point: chronic HIV } \\
\text { infection }\end{array}$ \\
\hline $\begin{array}{l}\text { IAVI Protocol C } \\
\text { (55) }\end{array}$ & 6 virus panel & $\mathrm{n}=439$ & $\begin{array}{c}\text { Broad }=2 \% \text { elite }>2,9 \% \text { strong }(1-2), 25 \% \text { moderate }(0.5-1) \text { and not broad }=46 \% \text { low }(0.1- \\
0.5), 18 \% \text { no breadth }\end{array}$ & Longitudinal: $0-4$ years \\
\hline Swiss Cohort (56) & 8 virus panel & $n=4484$ & $\begin{array}{c}\text { Cummulative scoring for } \% \text { neutralization. Elite }(\text { score }>15)=1.3 \% \text {, Broad (score 10-14) }= \\
\qquad 4 \% \text {, cross-neutralizing (score } 5-9)=15.6 \%\end{array}$ & $\begin{array}{l}\text { Single time point: }>1 \text { year off } \\
\text { treatment }\end{array}$ \\
\hline
\end{tabular}




\section{References and recommended reading:}

1. Wong-Staal F, Shaw GM, Hahn BH, Salahuddin SZ, Popovic M, Markham P, et al. Genomic diversity of human T-lymphotropic virus type III (HTLV-III). Science. 1985;229(4715):759-62.

2. Benn S, Rutledge R, Folks T, Gold J, Baker L, McCormick J, et al. Genomic heterogeneity of AIDS retroviral isolates from North America and Zaire. Science. 1985;230(4728):949-51.

3. Hahn BH, Gonda MA, Shaw GM, Popovic M, Hoxie JA, Gallo RC, et al. Genomic diversity of the acquired immune deficiency syndrome virus HTLVIII: different viruses exhibit greatest divergence in their envelope genes. Proceedings of the National Academy of Sciences of the United States of America. 1985;82(14):4813-7.

4. Starcich BR, Hahn BH, Shaw GM, McNeely PD, Modrow S, Wolf $\mathrm{H}$, et al. Identification and characterization of conserved and variable regions in the envelope gene of HTLV-III/LAV, the retrovirus of AIDS. Cell. 1986;45(5):63748.

5. Coffin J, Haase A, Levy JA, Montagnier L, Oroszlan S, Teich N, et al. What to call the AIDS virus? Nature. 1986;321(6065):10.

6. Weiss RA, Clapham PR, Weber JN, Dalgleish AG, Lasky LA, Berman PW. Variable and conserved neutralization antigens of human immunodeficiency virus. Nature. 1986;324(6097):572-5.

7. Robert-Guroff M, Brown M, Gallo RC. HTLV-III-neutralizing antibodies in patients with AIDS and AIDS-related complex. Nature. 1985;316(6023):724.

8. Weiss RA, Clapham PR, Cheingsong-Popov R, Dalgleish AG, Carne CA, Weller IV, et al. Neutralization of human T-lymphotropic virus type III by sera of AIDS and AIDS-risk patients. Nature. 1985;316(6023):69-72.

9. Ho DD, Sarngadharan MG, Hirsch MS, Schooley RT, Rota TR, Kennedy RC, et al. Human immunodeficiency virus neutralizing antibodies recognize several conserved domains on the envelope glycoproteins. Journal of virology. 1987;61(6):2024-8.

10. Nara PL, Robey WG, Gonda MA, Carter SG, Fischinger PJ. Absence of cytotoxic antibody to human immunodeficiency virus-infected cells in humans and its induction in animals after infection or immunization with purified envelope glycoprotein gp120. Proceedings of the National Academy of Sciences of the United States of America. 1987;84(11):3797-801.

11. Ranki A, Weiss SH, Valle SL, Antonen J, Krohn KJ. Neutralizing antibodies in HIV (HTLV-III) infection: correlation with clinical outcome and antibody response against different viral proteins. Clin Exp Immunol. 1987;69(2):231-9.

12. Robert-Guroff M, Giardina PJ, Robey WG, Jennings AM, Naugle CJ, Akbar AN, et al. HTLV-III neutralizing antibody development in transfusiondependent seropositive patients with beta-thalassemia. J Immunol. 1987;138(11):3731-6.

13. Robert-Guroff M, Oleske JM, Connor EM, Epstein LG, Minnefor AB, Gallo RC. Relationship between HTLV-III neutralizing antibody and clinical status of pediatric acquired immunodeficiency syndrome (AIDS) and AIDSrelated complex cases. Pediatr Res. 1987;21(6):547-50. 
14. Wendler I, Bienzle U, Hunsmann G. Neutralizing antibodies and the course of HIV-induced disease. AIDS Res Hum Retroviruses. 1987;3(2):15763.

15. Weiss RA, Clapham PR, McClure MO, McKeating JA, McKnight A, Dalgleish AG, et al. Human immunodeficiency viruses: neutralization and receptors. J Acquir Immune Defic Syndr. 1988;1(6):536-41.

16. Robert-Guroff M, Goedert JJ, Naugle CJ, Jennings AM, Blattner WA, Gallo RC. Spectrum of HIV-1 neutralizing antibodies in a cohort of homosexual men: results of a 6 year prospective study. AIDS Res Hum Retroviruses. 1988;4(5):343-50.

17. Dalgleish AG, Beverley PC, Clapham PR, Crawford DH, Greaves MF, Weiss RA. The CD4 (T4) antigen is an essential component of the receptor for the AIDS retrovirus. Nature. 1984;312(5996):763-7.

18. Kang CY, Nara P, Chamat S, Caralli V, Ryskamp T, Haigwood N, et al. Evidence for non-V3-specific neutralizing antibodies that interfere with gp120/CD4 binding in human immunodeficiency virus 1-infected humans. Proceedings of the National Academy of Sciences of the United States of America. 1991;88(14):6171-5.

19. Steimer KS, Scandella CJ, Skiles PV, Haigwood NL. Neutralization of divergent HIV-1 isolates by conformation-dependent human antibodies to Gp120. Science. 1991;254(5028):105-8.

20. Leonard CK, Spellman MW, Riddle L, Harris RJ, Thomas JN, Gregory TJ. Assignment of intrachain disulfide bonds and characterization of potential glycosylation sites of the type 1 recombinant human immunodeficiency virus envelope glycoprotein (gp120) expressed in Chinese hamster ovary cells. J Biol Chem. 1990;265(18):10373-82.

21. Cordonnier A, Montagnier L, Emerman M. Single amino-acid changes in HIV envelope affect viral tropism and receptor binding. Nature. 1989;340(6234):571-4.

22. Kowalski M, Ardman B, Basiripour L, Lu YC, Blohm D, Haseltine W, et al. Antibodies to CD4 in individuals infected with human immunodeficiency virus type 1. Proceedings of the National Academy of Sciences of the United States of America. 1989;86(9):3346-50.

23. Olshevsky U, Helseth E, Furman C, Li J, Haseltine W, Sodroski J. Identification of individual human immunodeficiency virus type $1 \mathrm{gp} 120$ amino acids important for CD4 receptor binding. Journal of virology.

1990;64(12):5701-7.

24. Sattentau QJ, Moore JP. Conformational changes induced in the human immunodeficiency virus envelope glycoprotein by soluble CD4 binding. The Journal of experimental medicine. 1991;174(2):407-15.

25. Deng H, Liu R, Ellmeier W, Choe S, Unutmaz D, Burkhart M, et al. Identification of a major co-receptor for primary isolates of HIV-1. Nature. 1996;381(6584):661-6.

26. Feng Y, Broder CC, Kennedy PE, Berger EA. HIV-1 entry cofactor: functional cDNA cloning of a seven-transmembrane, $G$ protein-coupled receptor. Science. 1996;272(5263):872-7.

27. Hill CM, Deng H, Unutmaz D, Kewalramani VN, Bastiani L, Gorny MK, et al. Envelope glycoproteins from human immunodeficiency virus types 1 and 2 and simian immunodeficiency virus can use human CCR5 as a coreceptor 
for viral entry and make direct CD4-dependent interactions with this chemokine receptor. Journal of virology. 1997;71(9):6296-304.

28. Moore JP, Sattentau QJ, Clapham PR. Enhancement of soluble CD4mediated HIV neutralization and gp 120 binding by CD4 autoantibodies and monoclonal antibodies. AIDS Res Hum Retroviruses. 1990;6(11):1273-9.

29. Sattentau QJ, Moore JP, Vignaux F, Traincard F, Poignard P.

Conformational changes induced in the envelope glycoproteins of the human and simian immunodeficiency viruses by soluble receptor binding. Journal of virology. 1993;67(12):7383-93.

30. Thali M, Moore JP, Furman C, Charles M, Ho DD, Robinson J, et al. Characterization of conserved human immunodeficiency virus type $1 \mathrm{gp} 120$ neutralization epitopes exposed upon gp120-CD4 binding. Journal of virology. 1993;67(7):3978-88.

31. Wu L, Gerard NP, Wyatt R, Choe H, Parolin C, Ruffing N, et al. CD4induced interaction of primary HIV-1 gp120 glycoproteins with the chemokine receptor CCR-5. Nature. 1996;384(6605):179-83.

32. Kwong PD, Wyatt R, Robinson J, Sweet RW, Sodroski J, Hendrickson WA. Structure of an HIV gp120 envelope glycoprotein in complex with the CD4 receptor and a neutralizing human antibody. Nature. 1998;393(6686):648-59.

33. Labrijn AF, Poignard P, Raja A, Zwick MB, Delgado K, Franti M, et al. Access of antibody molecules to the conserved coreceptor binding site on glycoprotein gp120 is sterically restricted on primary human immunodeficiency virus type 1. Journal of virology. 2003;77(19):10557-65. 34. Mondor I, Moulard M, Ugolini S, Klasse PJ, Hoxie J, Amara A, et al. Interactions among HIV gp120, CD4, and CXCR4: dependence on CD4 expression level, gp120 viral origin, conservation of the gp120 $\mathrm{COOH}$ - and $\mathrm{NH} 2$-termini and V1/V2 and V3 loops, and sensitivity to neutralizing antibodies. Virology. 1998;248(2):394-405.

35. Moulard M, Phogat SK, Shu Y, Labrijn AF, Xiao X, Binley JM, et al. Broadly cross-reactive HIV-1-neutralizing human monoclonal Fab selected for binding to gp120-CD4-CCR5 complexes. Proceedings of the National Academy of Sciences of the United States of America. 2002;99(10):6913-8. 36. McCoy LE, Weiss RA. Neutralizing antibodies to HIV-1 induced by immunization. The Journal of experimental medicine. 2013;210(2):209-23. 37. Goudsmit J, Debouck C, Meloen RH, Smit L, Bakker M, Asher DM, et al. Human immunodeficiency virus type 1 neutralization epitope with conserved architecture elicits early type-specific antibodies in experimentally infected chimpanzees. Proceedings of the National Academy of Sciences of the United States of America. 1988;85(12):4478-82.

38. Nara PL, Smit L, Dunlop N, Hatch W, Merges M, Waters D, et al. Emergence of viruses resistant to neutralization by V3-specific antibodies in experimental human immunodeficiency virus type 1 IIIB infection of chimpanzees. Journal of virology. 1990;64(8):3779-91.

39. Pincus SH, Messer KG, Schwartz DH, Lewis GK, Graham BS, Blattner WA, et al. Differences in the antibody response to human immunodeficiency virus-1 envelope glycoprotein (gp160) in infected laboratory workers and vaccinees. J Clin Invest. 1993;91(5):1987-96.

40. Weber JN, Clapham PR, Weiss RA, Parker D, Roberts C, Duncan J, et al. Human immunodeficiency virus infection in two cohorts of homosexual 
men: neutralising sera and association of anti-gag antibody with prognosis. Lancet. 1987;1(8525):119-22.

41. Albert J, Abrahamsson B, Nagy K, Aurelius E, Gaines H, Nystrom G, et al. Rapid development of isolate-specific neutralizing antibodies after primary HIV-1 infection and consequent emergence of virus variants which resist neutralization by autologous sera. Aids. 1990;4(2):107-12.

42. McKnight A, Clapham PR, Goudsmit J, Cheingsong-Popov R, Weber JN, Weiss RA. Development of HIV-1 group-specific neutralizing antibodies after seroconversion. Aids. 1992;6(8):799-802.

43. Aasa-Chapman MM, Hayman A, Newton P, Cornforth D, Williams I, Borrow $\mathrm{P}$, et al. Development of the antibody response in acute HIV-1 infection. Aids. 2004;18(3):371-81.

44. Richman DD, Wrin T, Little SJ, Petropoulos CJ. Rapid evolution of the neutralizing antibody response to HIV type 1 infection. Proceedings of the National Academy of Sciences of the United States of America. 2003;100(7):4144-9.

45. Wei X, Decker JM, Wang S, Hui H, Kappes JC, Wu X, et al. Antibody neutralization and escape by HIV-1. Nature. 2003;422(6929):307-12.

46. Fenyo EM, Heath A, Dispinseri S, Holmes H, Lusso P, Zolla-Pazner S, et al. International network for comparison of HIV neutralization assays: the NeutNet report. PLoS One. 2009;4(2):e4505.

47. Simek MD, Rida W, Priddy FH, Pung P, Carrow E, Laufer DS, et al. Human immunodeficiency virus type 1 elite neutralizers: individuals with broad and potent neutralizing activity identified by using a high-throughput neutralization assay together with an analytical selection algorithm. Journal of virology. 2009;83(14):7337-48.

48. Doria-Rose NA, Klein RM, Manion MM, O'Dell S, Phogat A, Chakrabarti $B$, et al. Frequency and phenotype of human immunodeficiency virus envelope-specific $B$ cells from patients with broadly cross-neutralizing antibodies. Journal of virology. 2009;83(1):188-99.

49. $\quad$ van Gils MJ, Euler Z, Schweighardt B, Wrin T, Schuitemaker H. Prevalence of cross-reactive HIV-1-neutralizing activity in HIV-1-infected patients with rapid or slow disease progression. Aids. 2009;23(18):2405-14. 50. Gray ES, Taylor N, Wycuff D, Moore PL, Tomaras GD, Wibmer CK, et al. Antibody specificities associated with neutralization breadth in plasma from human immunodeficiency virus type 1 subtype C-infected blood donors. Journal of virology. 2009;83(17):8925-37.

51. Euler Z, van Gils MJ, Bunnik EM, Phung P, Schweighardt B, Wrin T, et al. Cross-reactive neutralizing humoral immunity does not protect from HIV type 1 disease progression. The Journal of infectious diseases. 2010;201(7):1045-53.

52. Gray ES, Madiga MC, Hermanus T, Moore PL, Wibmer CK, Tumba NL, et al. The neutralization breadth of HIV-1 develops incrementally over four years and is associated with CD4+ T cell decline and high viral load during acute infection. Journal of virology. 2011;85(10):4828-40.

53. Mikell I, Sather DN, Kalams SA, Altfeld M, Alter G, Stamatatos L. Characteristics of the earliest cross-neutralizing antibody response to HIV-1. PLoS pathogens. 2011;7(1):e1001251. 
54. Hraber P, Seaman MS, Bailer RT, Mascola JR, Montefiori DC, Korber BT. Prevalence of broadly neutralizing antibody responses during chronic HIV-1 infection. Aids. 2014;28(2):163-9.

55. Landais E, Huang X, Havenar-Daughton C, Murrell B, Price MA, Wickramasinghe L, et al. Broadly Neutralizing Antibody Responses in a Large Longitudinal Sub-Saharan HIV Primary Infection Cohort. PLoS pathogens. 2016;12(1):e1005369.

* This study follows a large longitudinal cohort from seroconversion to elite neutralization. The level of breadth found across the sampled timepoints provides new insight into the development of neutralization breadth during infection.

56. Rusert P, Kouyos RD, Kadelka C, Ebner H, Schanz M, Huber M, et al. Determinants of HIV-1 broadly neutralizing antibody induction. Nature medicine. 2016;22(11):1260-7.

* This is the largest study ( $>4000$ individuals) designed to determine features associated with broad serum neutralization. They identify a host factor (ethnicity) to be significantly linked to bnAb development.

57. Burton DR, Mascola JR. Antibody responses to envelope glycoproteins in HIV-1 infection. Nature immunology. 2015;16(6):571-6.

58. McCoy LE, Burton DR. Identification and specificity of broadly neutralizing antibodies against HIV. Immunol Rev. 2017; In press.

59. Walker LM, Simek MD, Priddy F, Gach JS, Wagner D, Zwick MB, et al. A limited number of antibody specificities mediate broad and potent serum neutralization in selected HIV-1 infected individuals. PLoS pathogens. 2010;6(8):e1001028.

60. Georgiev IS, Doria-Rose NA, Zhou T, Kwon YD, Staupe RP, Moquin S, et al. Delineating antibody recognition in polyclonal sera from patterns of HIV1 isolate neutralization. Science. 2013;340(6133):751-6.

61. Bhiman JN, Anthony C, Doria-Rose NA, Karimanzira O, Schramm CA, Khoza T, et al. Viral variants that initiate and drive maturation of V1V2directed HIV-1 broadly neutralizing antibodies. Nature medicine. 2015;21(11):1332-6.

62. Doria-Rose NA, Schramm CA, Gorman J, Moore PL, Bhiman JN, DeKosky BJ, et al. Developmental pathway for potent V1V2-directed HIVneutralizing antibodies. Nature. 2014;509(7498):55-62.

63. Liao HX, Lynch R, Zhou T, Gao F, Alam SM, Boyd SD, et al. Coevolution of a broadly neutralizing HIV-1 antibody and founder virus. Nature. 2013;496(7446):469-76.

64. Moore PL, Gray ES, Sheward D, Madiga M, Ranchobe N, Lai Z, et al. Potent and broad neutralization of HIV-1 subtype $C$ by plasma antibodies targeting a quaternary epitope including residues in the V2 loop. Journal of virology. 2011;85(7):3128-41.

65. Wu X, Zhang Z, Schramm CA, Joyce MG, Kwon YD, Zhou T, et al. Maturation and Diversity of the VRC01-Antibody Lineage over 15 Years of Chronic HIV-1 Infection. Cell. 2015;161(3):470-85.

66. Zhou T, Zhu J, Wu X, Moquin S, Zhang B, Acharya P, et al. Multidonor analysis reveals structural elements, genetic determinants, and maturation pathway for HIV-1 neutralization by VRC01-class antibodies. Immunity. 2013;39(2):245-58.

67. Zhou T, Lynch RM, Chen L, Acharya P, Wu X, Doria-Rose NA, et al. Structural Repertoire of HIV-1-Neutralizing Antibodies Targeting the CD4 Supersite in 14 Donors. Cell. 2015;161(6):1280-92. 
68. Walker LM, Huber M, Doores KJ, Falkowska E, Pejchal R, Julien JP, et al. Broad neutralization coverage of HIV by multiple highly potent antibodies. Nature. 2011;477(7365):466-70.

69. Kong L, Lee JH, Doores KJ, Murin CD, Julien JP, McBride R, et al. Supersite of immune vulnerability on the glycosylated face of HIV-1 envelope glycoprotein gp120. Nature structural \& molecular biology. 2013;20(7):796803.

70. Mouquet H, Scharf L, Euler Z, Liu Y, Eden C, Scheid JF, et al. Complex-type N-glycan recognition by potent broadly neutralizing HIV antibodies. Proceedings of the National Academy of Sciences of the United States of America. 2012;109(47):E3268-77.

71. Gao F, Bonsignori M, Liao HX, Kumar A, Xia SM, Lu X, et al. Cooperation of $B$ cell lineages in induction of HIV-1-broadly neutralizing antibodies. Cell. 2014;158(3):481-91.

72. Bonsignori M, Zhou T, Sheng Z, Chen L, Gao F, Joyce MG, et al. Maturation Pathway from Germline to Broad HIV-1 Neutralizer of a CD4Mimic Antibody. Cell. 2016;165(2):449-63.

* * This article explains how a previously identified "helper" antibody lineage eventually mutated to achieve broad neutralization activity.

73. Sok D, Laserson U, Laserson J, Liu Y, Vigneault F, Julien JP, et al. The effects of somatic hypermutation on neutralization and binding in the PGT121 family of broadly neutralizing HIV antibodies. PLoS pathogens. 2013;9(11):e1003754.

74. Steichen JM, Kulp DW, Tokatlian T, Escolano A, Dosenovic P, Stanfield RL, et al. HIV Vaccine Design to Target Germline Precursors of Glycan-Dependent Broadly Neutralizing Antibodies. Immunity. 2016;45:1-14. 75. Escolano A, Steichen JM, Dosenovic P, Kulp DW, Golijanin J, Sok D, et al. Sequential Immunization Elicits Broadly Neutralizing Anti-HIV-1 Antibodies in Ig Knockin Mice. Cell. 2016;166(6):1445-58 e12.

76. McCoy LE, van Gils MJ, Ozorowski G, Messmer T, Briney B, Voss JE, et al. Holes in the Glycan Shield of the Native HIV Envelope Are a Target of Trimer-Elicited Neutralizing Antibodies. Cell Rep. 2016;16(9):2327-38.

77. Moore PL, Gray ES, Wibmer CK, Bhiman JN, Nonyane M, Sheward DJ, et al. Evolution of an HIV glycan-dependent broadly neutralizing antibody epitope through immune escape. Nature medicine. 2012;18(11):1688-92.

78. Garces F, Lee JH, de Val N, Torrents de la Pena A, Kong L, Puchades C, et al. Affinity Maturation of a Potent Family of HIV Antibodies Is Primarily Focused on Accommodating or Avoiding Glycans. Immunity. 2015;43(6):1053-63.

79. Briney B, Sok D, Jardine JG, Kulp DW, Skog P, Menis S, et al. Tailored Immunogens Direct Affinity Maturation toward HIV Neutralizing Antibodies. Cell. 2016;166(6):1459-70 e11.

80. Moore PL, Williamson C, Morris L. Virological features associated with the development of broadly neutralizing antibodies to HIV-1. Trends in microbiology. 2015;23(4):204-11.

81. Sather DN, Armann J, Ching LK, Mavrantoni A, Sellhorn G, Caldwell Z, et al. Factors associated with the development of cross-reactive neutralizing antibodies during human immunodeficiency virus type 1 infection. Journal of virology. 2009;83(2):757-69. 
82. Keele BF, Giorgi EE, Salazar-Gonzalez JF, Decker JM, Pham KT, Salazar MG, et al. Identification and characterization of transmitted and early founder virus envelopes in primary HIV-1 infection. Proceedings of the National Academy of Sciences of the United States of America. 2008;105(21):7552-7.

83. Piantadosi A, Panteleeff D, Blish CA, Baeten JM, Jaoko W, McClelland $\mathrm{RS}$, et al. Breadth of neutralizing antibody response to human immunodeficiency virus type 1 is affected by factors early in infection but does not influence disease progression. Journal of virology. 2009;83(19):10269-74. 84. Burton DR, Poignard P, Stanfield RL, Wilson IA. Broadly neutralizing antibodies present new prospects to counter highly antigenically diverse viruses. Science. 2012;337(6091):183-6.

85. Ndung'u T, Weiss RA. On HIV diversity. Aids. 2012;26(10):1255-60. 86. Geiss Y, Dietrich U. Catch Me If You Can--The Race Between HIV and Neutralizing Antibodies. AIDS reviews. 2015;17(2):107-13.

87. Hessell AJ, Haigwood NL. Neutralizing antibodies and control of HIV: moves and countermoves. Curr HIVIAIDS Rep. 2012;9(1):64-72.

88. Dreja H, O'Sullivan E, Pade C, Greene KM, Gao H, Aubin K, et al. Neutralization activity in a geographically diverse East London cohort of human immunodeficiency virus type 1-infected patients: clade $\mathrm{C}$ infection results in a stronger and broader humoral immune response than clade $B$ infection. The Journal of general virology. 2010;91(Pt 11):2794-803.

89. van den Kerkhof TL, Feenstra KA, Euler Z, van Gils MJ, Rijsdijk LW, Boeser-Nunnink BD, et al. HIV-1 envelope glycoprotein signatures that correlate with the development of cross-reactive neutralizing activity. Retrovirology. 2013;10:102.

90. Wibmer CK, Bhiman JN, Gray ES, Tumba N, Abdool Karim SS, Williamson $\mathrm{C}$, et al. Viral escape from HIV-1 neutralizing antibodies drives increased plasma neutralization breadth through sequential recognition of multiple epitopes and immunotypes. PLoS pathogens. 2013;9(10):e1003738. 91. Derdeyn CA, Moore PL, Morris L. Development of broadly neutralizing antibodies from autologous neutralizing antibody responses in HIV infection. Curr Opin HIV AIDS. 2014;9(3):210-6.

92. Locci M, Havenar-Daughton C, Landais E, Wu J, Kroenke MA, Arlehamn CL, et al. Human circulating PD-1+CXCR3-CXCR5+ memory Tfh cells are highly functional and correlate with broadly neutralizing HIV antibody responses. Immunity. 2013;39(4):758-69.

93. Yamamoto T, Lynch RM, Gautam R, Matus-Nicodemos R, Schmidt $\mathrm{SD}$, Boswell KL, et al. Quality and quantity of TFH cells are critical for broad antibody development in SHIVAD8 infection. Science translational medicine. 2015;7(298):298ra120.

94. Euler Z, van Gils MJ, Boeser-Nunnink BD, Schuitemaker H, van Manen D. Genome-wide association study on the development of cross-reactive neutralizing antibodies in HIV-1 infected individuals. PLoS One. 2013;8(1):e54684.

95. van den Kerkhof TL, Euler Z, van Gils MJ, Boeser-Nunnink BD, Schuitemaker H, Sanders RW. Early development of broadly reactive HIV-1 neutralizing activity in elite neutralizers. Aids. 2014;28(8):1237-40. 
96. Simonich CA, Williams KL, Verkerke HP, Williams JA, Nduati R, Lee $\mathrm{KK}$, et al. HIV-1 Neutralizing Antibodies with Limited Hypermutation from an Infant. Cell. 2016;166(1):77-87.

97. Kwong PD, Mascola JR. Human antibodies that neutralize HIV-1: identification, structures, and B cell ontogenies. Immunity. 2012;37(3):412-25. 98. Li M, Gao F, Mascola JR, Stamatatos L, Polonis VR, Koutsoukos M, et al. Human immunodeficiency virus type 1 env clones from acute and early subtype B infections for standardized assessments of vaccine-elicited neutralizing antibodies. Journal of virology. 2005;79(16):10108-25.

99. Seaman MS, Janes H, Hawkins N, Grandpre LE, Devoy C, Giri A, et al. Tiered categorization of a diverse panel of HIV-1 Env pseudoviruses for assessment of neutralizing antibodies. Journal of virology. 2010;84(3):143952.

100. Binley JM, Wrin T, Korber B, Zwick MB, Wang M, Chappey C, et al. Comprehensive cross-clade neutralization analysis of a panel of anti-human immunodeficiency virus type 1 monoclonal antibodies. Journal of virology. 2004;78(23):13232-52.

101. Rong R, Li B, Lynch RM, Haaland RE, Murphy MK, Mulenga J, et al. Escape from autologous neutralizing antibodies in acute/early subtype C HIV1 infection requires multiple pathways. PLoS pathogens. 2009;5(9):e1000594. 102. Bunnik EM, Pisas L, van Nuenen AC, Schuitemaker H. Autologous neutralizing humoral immunity and evolution of the viral envelope in the course of subtype $B$ human immunodeficiency virus type 1 infection. Journal of virology. 2008;82(16):7932-41.

103. Bar KJ, Tsao CY, lyer SS, Decker JM, Yang Y, Bonsignori M, et al. Early low-titer neutralizing antibodies impede HIV-1 replication and select for virus escape. PLoS pathogens. 2012;8(5):e1002721.

104. van Gils MJ, Bunnik EM, Burger JA, Jacob Y, Schweighardt B, Wrin T, et al. Rapid escape from preserved cross-reactive neutralizing humoral immunity without loss of viral fitness in HIV-1-infected progressors and longterm nonprogressors. Journal of virology. 2010;84(7):3576-85.

105. Pellegrin I, Legrand E, Neau D, Bonot P, Masquelier B, Pellegrin JL, et al. Kinetics of appearance of neutralizing antibodies in 12 patients with primary or recent HIV-1 infection and relationship with plasma and cellular viral loads. J Acquir Immune Defic Syndr Hum Retrovirol. 1996;11(5):438-47. 106. Pilgrim AK, Pantaleo G, Cohen OJ, Fink LM, Zhou JY, Zhou JT, et al. Neutralizing antibody responses to human immunodeficiency virus type 1 in primary infection and long-term-nonprogressive infection. The Journal of infectious diseases. 1997;176(4):924-32.

107. Aasa-Chapman MM, Cheney KM, Hue S, Forsman A, O'Farrell S, Pellegrino $P$, et al. In vivo emergence of HIV-1 highly sensitive to neutralizing antibodies. PLoS One. 2011;6(8):e23961.

108. Huang KH, Bonsall D, Katzourakis A, Thomson EC, Fidler SJ, Main J, et al. B-cell depletion reveals a role for antibodies in the control of chronic HIV-1 infection. Nature communications. 2010;1:102.

109. Frost SD, Wrin T, Smith DM, Kosakovsky Pond SL, Liu Y, Paxinos E, et al. Neutralizing antibody responses drive the evolution of human immunodeficiency virus type 1 envelope during recent HIV infection. Proceedings of the National Academy of Sciences of the United States of America. 2005;102(51):18514-9. 
110. Bouvin-Pley M, Morgand M, Meyer L, Goujard C, Moreau A, Mouquet $\mathrm{H}$, et al. Drift of the HIV-1 envelope glycoprotein gp120 toward increased neutralization resistance over the course of the epidemic: a comprehensive study using the most potent and broadly neutralizing monoclonal antibodies. Journal of virology. 2014;88(23):13910-7.

111. Euler Z, Bunnik EM, Burger JA, Boeser-Nunnink BD, Grijsen ML, Prins $\mathrm{JM}$, et al. Activity of broadly neutralizing antibodies, including PG9, PG16, and VRC01, against recently transmitted subtype B HIV-1 variants from early and late in the epidemic. Journal of virology. 2011;85(14):7236-45.

112. Hessell AJ, Haigwood NL. Animal models in HIV-1 protection and therapy. Curr Opin HIV AIDS. 2015;10(3):170-6.

113. Schoofs T, Klein F, Braunschweig M, Kreider EF, Feldmann A, Nogueira L, et al. HIV-1 therapy with monoclonal antibody 3BNC117 elicits host immune responses against HIV-1. Science. 2016;352(6288):997-1001. 114. Klein F, Nogueira L, Nishimura Y, Phad G, West AP, Jr., HalperStromberg A, et al. Enhanced HIV-1 immunotherapy by commonly arising antibodies that target virus escape variants. The Journal of experimental medicine. 2014;211(12):2361-72. 